\title{
Crystal Structures of Human
}

\section{$17 \beta$-Hydroxysteroid Dehydrogenase Type 1 Complexed with the Dual-Site Inhibitor EM-139}

\author{
Tang Li ${ }^{1}$, Daowei Zhu' ${ }^{1}$, Fernand Labrie ${ }^{2}$, Shengxiang Lin ${ }^{1}$ \\ ${ }^{1} \mathrm{CHU}$ de Quebec Research Center and Department of Molecular Medicine, Laval University, Quebec City, Canada \\ ${ }^{2}$ EndoCeutics Inc., Quebec City, Canada \\ Email: sxlin@crchul.ulaval.ca
}

How to cite this paper: Li, T., Zhu, D.W., Labrie, F. and Lin, S.X. (2018) Crystal Structures of Human $17 \beta$-Hydroxysteroid Dehydrogenase Type 1 Complexed with the Dual-Site Inhibitor EM-139. Health, 10, 1079-1089.

https://doi.org/10.4236/health.2018.108081

Received: July 12, 2018

Accepted: August 13, 2018

Published: August 16, 2018

Copyright (c) 2018 by authors and Scientific Research Publishing Inc. This work is licensed under the Creative Commons Attribution International License (CC BY 4.0).

http://creativecommons.org/licenses/by/4.0/

\begin{abstract}
Human $17 \beta$-hydroxysteroid dehydrogenase type 1 (17 $\beta$-HSD1) catalyzes the biosynthesis of the most potent natural estrogen $17 \beta$-estradiol (E2) from estrone (E1) in the ovary and peripheral tissues, playing a pivotal role in the progression of estrogen-dependent diseases. $N$ - $n$-Butyl- $N$-methyl-1l-(16' $\alpha$-chloro$3^{\prime}, 17^{\prime} \beta$-dihydroxyestra-1', $3^{\prime}, 5^{\prime}\left(10^{\prime}\right)$-trien-7' $\alpha$-yl)undecanamide (EM-139) was previously described as a dual-site inhibitor that can inhibit $17 \beta$-HSD1 transforming E1 into E2 and also inhibit estrogen receptor. In the present report, we describe the co-crystallization of EM-139 with $17 \beta$-HSD1 as well as the analysis of the three-dimensional structure of the enzyme/inhibitor complex. The crystal is grown under similar condition as native crystals, whereas the space group is changed to I121 never observed in other $17 \beta$-HSD1 crystals before. The steroidal moiety of the bound EM-139 molecule has shown a binding pattern similar to $\mathrm{E} 2$ in the $\mathrm{E} 2$ binary complex. The O-3 of the inhibitor develops hydrogen bonds with residues $\mathrm{His}^{221}$ and $\mathrm{Glu}^{282}$, whereas the $\mathrm{O}-17$ makes hydrogen bonds with $\mathrm{Ser}^{142}$ and $\mathrm{Tyr}^{155}$. The bulky $7 \alpha$-alkyl moiety of the inhibitor, which is essential for its anti-estrogenic activity but cannot be defined in the electron density, may compromise the inhibitory effect of EM-139 to $17 \beta$-HSD1. Moreover, the $16 \alpha$-Cl atom shows no obvious interaction with surrounding residues. The atomic level understanding of the inhibitory mechanism of EM-139 provides important information for the inhibitor design of $17 \beta$-HSD1, which will facilitate future development of more potent and selective inhibitors of the enzyme for therapeutic purposes.
\end{abstract}

\section{Keywords}

$17 \beta$-HSD1, Inhibitor, Complex Structure, Estrogen-Dependent Diseases 


\section{Introduction}

Seventeen $\beta$-hydroxysteroid dehydrogenase type 1 (17 $\beta$-HSD1, EC. 1.1.1.62) catalyzes the $\mathrm{NAD}(\mathrm{P}) \mathrm{H}$ dependent conversion of estrone (E1) to the most potent estrogen, $17 \beta$-estradiol (E2) [1]. E2 is well known to play a crucial role in the progression and development of several estrogen-dependent diseases (EDD). Increased E2 levels as well as up-regulated $17 \beta$-HSD1 expression indicate the involvement of the enzyme in EDDs, such as breast cancer [2] [3], endometrial cancer [4] [5], endometriosis [6] [7] [8], and ovarian cancer [9]. Moreover, patients with tumors that have high mRNA levels of $17 \beta$-HSD1 have significantly shortened disease-free and overall survival [10] [11] [12]. Therefore, blocking the production of E2 through the specific inhibition of $17 \beta$-HSD1 activity is considered to be of therapeutic benefit in the treatment of EDDs.

Over the past decades, major efforts from many different laboratories have been devoted to developing highly selective inhibitors of the key steroidogenic enzyme $17 \beta$-HSD1, yielding several lead compounds with significant inhibitory activity [13] [14]. However, due to the lack of specificity, especially for the presence of undesired estrogenic activity, no inhibitor has yet reached the stage of clinical trials [15] [16] [17] [18]. $N$ - $n$-Butyl- $N$-methyl-11-(16' $\alpha$-chloro-3',17' $\beta$ dihydroxyes-tra-1',3',5'(10')-trien-7' $\alpha$-yl) undecanamide (EM-139) is a $7 \alpha$-alkyl, $16 \alpha$-halo estradiol derivative which was first synthesized as a pure antiestrogen (Figure 1) [19]. Following experiments demonstrated its inhibitory effect on $17 \beta$-HSD1 activity with a $K_{i}$ of $6 \mu \mathrm{M}$ [20]. Thus the compound was defined as a dual-site inhibitor which possesses inhibitory effect on estrogen receptor and on the estrogen formation [21]. Although this compound was proven to be a non-selective inhibitor of the $17 \beta$-HSD family members [22], study of the EM-139/17 $\beta$-HSD1 complex structure should help us to better understand the inhibitory mechanism of the dual-site inhibitor, thus facilitating further inhibitor design of the enzyme.

Previously, we have reported the crystallization of the $17 \beta$-HSD1/EM-139 complex using both co-crystallization and soaking methods [23]. The crystals obtained were isomorphous to the native crystals with a monoclinic space group C2 [23]. After careful analysis of the structures, the inhibitor couldn't be identified at the binding site of the enzyme due to poor electron density. In the present study, we optimized the co-crystallization procedure and successfully obtained complex crystals with a unique space group never observed in $17 \beta$-HSD1 complexes before. The clear electron density at the binding site indicated the presence of the dual-site inhibitor in the enzyme complex.

\section{Materials and Methods}

\subsection{Protein Preparation and Co-Crystallization}

The $17 \beta$-HSD1 enzyme was expressed in Sf9 insect cells and purified as described previously [24]. After the measurement of specific activity [25], the purified enzyme was concentrated to a final concentration of $15 \mathrm{mg} / \mathrm{ml}$ in the pres- 
ence of $0.06 \% \beta$-octyl glucoside ( $\beta$-OG), and then subjected to a buffer change procedure [26] via centricon (Emdmillipore, USA) to saturate the enzyme with the inhibitor EM-139. The co-crystallization experiment was carried out using the vapor diffusion method at room temperature. Crystals were obtained under conditions containing 22\% - 26\% (w/v) polyethyleneglycol (PEG) 4000, $0.15 \mathrm{M}$ magnesium chloride, and 0.1 M HEPES buffered to $\mathrm{pH}$ 7.5.

\subsection{Data Collection and Structure Determination}

The X-ray diffraction data of the $17 \beta$-HSD1-EM-139 crystals were collected at $100 \mathrm{~K}$ using synchrotron radiation at Advanced Photon Source (APS) beamline 31-LRL-CAT (Chicago, USA) equipped with a MAR CCD $165 \mathrm{~mm}$ detector at a wavelength of $0.9793 \AA$. The dataset was indexed and intergraded using MOSFLM [27], and scaled with SCALA [28] from the CCP4 suite [29]. The structure was solved by molecular replacement with Molrep [30] using a reported $17 \beta$-HSD1 coordinate (PDB code 1JTV) [31] as search model. The initial model was subjected to multiple rounds of auto-refinement using Refmac [32] and manual rebuild using Coot [33]. Missing portions of the models, inhibitor EM-139, glycerol, polyethylene glycol, and water molecules were progressively added with great caution during the refinement procedure. The final model was verified with PROCHECK [34]. Molecular graphics were presented using the Pymol software (version 2.0 Schrödinger, LLC).

\section{Results}

Crystal utilized in this study belonged to space group I121 and each asymmetric unit contained a dimer, which is known to be the functional unit of the enzyme [25]. The complex structure was refined at $2 \AA$ with good stereochemistries [35], and the quality of the final model can be assessed in Table 1. Similar to most previously reported $17 \beta$-HSD1 structures, the highly flexible $\beta \mathrm{F} \alpha \mathrm{G}$-loop (amino acids $\mathrm{Phe}^{192}$ to $\mathrm{Leu}^{197}$ ) as well as the C-terminal end of the protein (amino acids 286 to 327) cannot be defined in the electron density (Figure 2) [36] [37] [38] [39].

In the binary complex structure, EM-139 has definable electron density in the A subunit of the dimeric enzyme. However, the ligand density in the B subunit is poorly defined, similar to previously described complex with equilin [40]. Accordingly the ligand was not included in the B subunit of the final model. Even for the A subunit, only the steroid moiety of EM-139 can be defined but with a high average B-factor $\left(97.5 \AA^{2}\right.$ ), whereas the $7 \alpha$-alkyl side chain of the inhibitor cannot be defined in the electron density (Figure 3). This high flexibility of the inhibitor is in accordance with its relatively low affinity for the enzyme [20].

\section{Discussion}

The space group of $17 \beta$-HSD 1 crystals can be affected by the presence of cations in the crystallization conditions [41]. The space group of crystals obtained in the 
Table 1. Data collection and refinement statistics.

\begin{tabular}{|c|c|}
\hline Parameter & $17 \beta$-HSD1-EM-139 \\
\hline \multicolumn{2}{|l|}{ Data Collection } \\
\hline Space group & $\mathrm{I} 121$ \\
\hline \multicolumn{2}{|l|}{ Unit cell } \\
\hline a,b,c $(\AA)$ & $120.76,42.19,122.67$ \\
\hline$\alpha, \beta, \gamma\left({ }^{\circ}\right)$ & $90,102.07,90$ \\
\hline Resolution range ( $(\AA)$ & $35.67-2.00(2.11-2.00)^{\mathrm{a}}$ \\
\hline Number of reflections & $138,222(20,278)$ \\
\hline Unique reflections & $38,108(5536)$ \\
\hline Completeness (\%) & $92.7(92.5)$ \\
\hline $\mathrm{I} / \sigma(\mathrm{I})$ & $8.5(2.8)$ \\
\hline Rmeans $^{\mathrm{b}}$ & $0.086(0.315)$ \\
\hline Multiplicity & $3.6(3.7)$ \\
\hline Wilson B-factor $\left(\AA^{2}\right)$ & 30.5 \\
\hline \multicolumn{2}{|l|}{ Refinement } \\
\hline R-work ${ }^{c}$ & 0.20 \\
\hline$R-$ free $^{d}$ & 0.24 \\
\hline \multicolumn{2}{|l|}{ r.m.s.d } \\
\hline Bond lengths $(\AA ̊)$ & 0.010 \\
\hline Bond angles $\left({ }^{\circ}\right)$ & 1.483 \\
\hline \multicolumn{2}{|l|}{ Ramachandran plot $(\%)$} \\
\hline Most favored regions & 94.4 \\
\hline Additional allowed regions & 5.6 \\
\hline Generously allowed regions & 0.0 \\
\hline Disallowed regions & 0.0 \\
\hline Average $\mathrm{B}$, all atoms $\left(\AA^{2}\right)$ & 42.0 \\
\hline PDB ID & $6 \mathrm{DTP}$ \\
\hline
\end{tabular}

a. Data statistics for the outer shell are given in parentheses. b. The redundancy-independent $R_{\text {merge }} / R_{\text {sym }}$, $R_{\text {means }}=\sum_{h k l} \sqrt{\frac{n}{n-1}} \sum_{i=1}^{n}\left|I_{h k l, i}-\left\langle I_{h k l}\right\rangle\right| / \sum_{h k l} \sum_{i} I_{h k l, i} \quad$ c. $\quad R_{\text {work }}=\sum_{h l l}|| F_{o b s}(h k l)|-| F_{\text {calc }}(h k l)|| / \sum_{h k l}\left|F_{o b s}(h k l)\right| . \mathrm{d}$. $R_{\text {free }}=$ the cross-validation $R$ factor for $5 \%$ of reflections against which the model was not refined. e. Calculated with PROCHECK.

presence of $\mathrm{Mg}^{2+}$ and $\mathrm{Mn}^{2+}$ belong to $\mathrm{C} 2$, whereas crystals grown under conditions with $\mathrm{Li}^{+}$and $\mathrm{Na}^{+}$had a space group of $\mathrm{P}_{2} 2_{1} 2_{1}$ [41]. Despite the presence of $\mathrm{Mg}^{2+}$, the space group of the co-crystallized EM-139 complex crystals has been changed to I121, not observed in any other reported $17 \beta$-HSD1 structures. The change in space group may be due to the long alkyl side chain at the $\mathrm{C} 7$ of EM-139, which may affect the packing during crystal growth.

When the EM-139 binary and E2 binary (PDB ID 1IOL [37]) complexes as 
<smiles>[R7][C@H]1Cc2cc(O)ccc2[C@@]2(C)CC[C@@]([CH])(C)[C@@H]([R20])C[C@H]12</smiles>

$\mathrm{E}_{2}$ (estradiol): $\mathrm{R}_{7}=\mathrm{H}, \mathrm{R}_{16}=\mathrm{H}$

EM-139: $\mathrm{R}_{7}=\left(\mathrm{CH}_{2}\right)_{10} \mathrm{CONBuMe}, \mathrm{R}_{16}=\mathrm{Cl}$

Figure 1. Structure of dual-site inhibitor $N$-n-Butyl- $N$-methyl-1l-(16' $\alpha$-chloro-3',17' $\beta$ dihydroxyestra-1',3',5'(10')-trien-7' $\alpha$-yl)undecanamide (EM-139).
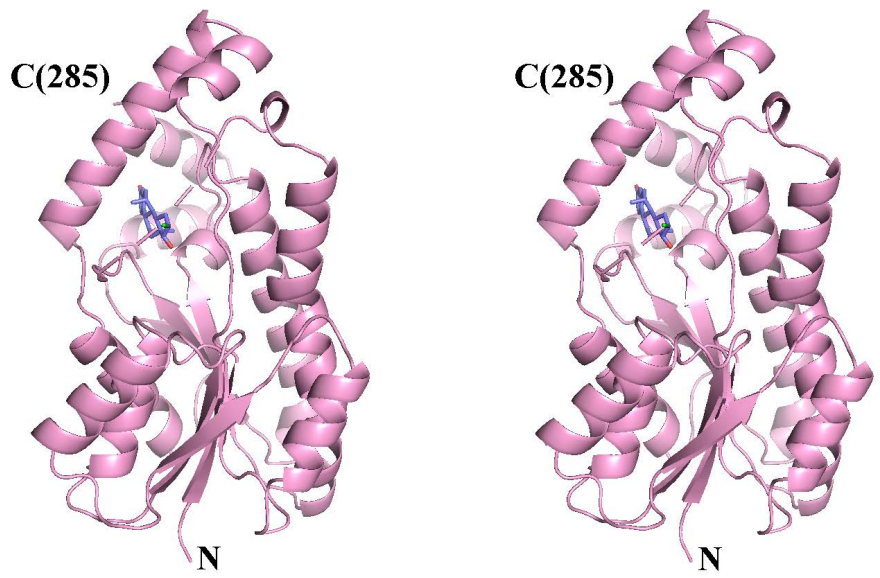

Figure 2. Stereo representation of the overall structure of A subunit of $17 \beta$-HSD1-EM139 complex. The protein molecule is shown in cartoon and colored in pink. The bound EM-139 molecule is depicted as stick and colored in blue. The N-terminus and the C-terminus of the protein molecule are indicated. Segment of residues 190-197, which unable to be defined in the electron density, is represented as dash line.

well as the apo structure of $17 \beta$-HSD1 (PDB ID 1BHS [42]) are superimposed, a similar conformation is observed at the steroid binding site of the enzyme (Figure 4(a)). The root-mean-square deviation (RMSD) for all paired C $\alpha$ atoms obtained between EM-139 complex and apo structure is $0.456 \AA$, similar to the value obtained between EM-139 and E2 complexes (0.508 $\mathrm{A})$. It is worth mentioning that the position observed for the steroidal moiety of EM-139 has roughly $9^{\circ}$ rotation around the axis at the $\mathrm{C}-3$ atom and perpendicular to its $\beta$-face, when compared with the position of E2. This leads to the shifting of the O-17 by $1.4 \AA$ as compared with the position of its counterpart in the E2 complex (Figure 4(b) and Figure 4(c)). As a result, the bifurcated hydrogen bonds between the O-17 of EM-139 with $\operatorname{Ser}^{142}$ and $\mathrm{Tyr}^{155}$ (3.5 and $3.2 \AA$, respectively) are established, although the bond distances differ from their counterparts observed in the E2 complex (3.1 and $3.5 \AA$, respectively) [37]. Moreover, the bifurcated hydrogen bond between the 3-hydroxyl group of EM-139 with $\mathrm{His}^{221}$ and 

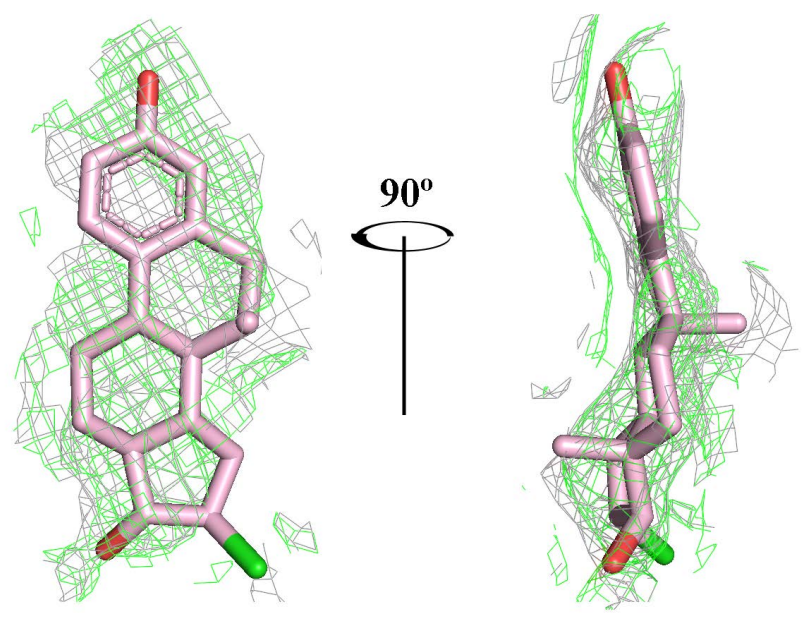

Figure 3. Front and side views of the electron density of EM-139 in the 17 $\beta$-HSD1-EM139 complex structure. EM-139 (ligand ID EM9) was shown in the omit $F_{O}-F_{C}$ and $2 F_{O}-F_{C}$ electron density. $2 F O-F C$ map draw in gray and contoured at $0.8 \sigma, F o-F C$ map draw in green and contoured at $1.5 \sigma$. The occupancy of the inhibitor was refined to 1 . No significant negative density features were present in the region of binding site.

$\operatorname{Glu}^{282}$ (3.2 and $3.5 \AA$, respectively) at the recognition end of the steroid binding cleft is conserved. Although much weaker as compared to their counterparts in the E2 complex (3.1 and $2.7 \AA$, respectively) [37], these hydrogen bonds are essential for stabilizing the inhibitor in the steroid binding cavity together with the hydrogen bonds at the O-3 of EM-139.

The $7 \alpha$-alkyl moiety of EM-139 is facing toward the outside of the steroid binding cavity which is apparently accommodated by the $\beta \mathrm{F} \alpha \mathrm{G}^{\prime}$-loop. However, both the $7 \alpha$-alkyl side chain of the inhibitor and the $\beta \mathrm{F} \alpha \mathrm{G}$-loop of the enzyme are unable to be defined by electron density due to their high degree of flexibility. This bulky $7 \alpha$-alkyl side chain is essential for the inhibitor to possess anti-estrogenic activity [43]. It is also safe to conclude that the $\alpha$ conformation of the C-7 is essential for this compound to be able to bind with $17 \beta$-HSD1. Similar results can also be observed at the C-16 of the inhibitor where a $16 \beta$ halogen atom may have steric hindrance with $\mathrm{Tyr}^{155}$. However, no obvious interaction is observed between the $16 \alpha-\mathrm{Cl}$ atom and surrounding residues (Figure 4 (b) and Figure $4(\mathrm{c})$ ).

\section{Conclusion}

The present work was aimed at investigating the molecular basis of the inhibitory mechanism of the dual-site inhibitor EM-139 in 17 $\beta$-HSD1. We successfully co-crystallized and solved the crystal structure of $17 \beta$-HSD1 in complex with the inhibitor. Through comparative analyses of EM-139 binary complexes and previously reported E2 binary complex as well as the apo structure, we observed a similar binding pattern of the inhibitor to the enzyme. The bifurcated hydrogen bonds between the O-3 of the inhibitor and the recognition end $\left(\mathrm{His}^{221}\right.$ and $\mathrm{Glu}^{282}$ ) of the binding site as well as the $\mathrm{O}-17$ of the inhibitor and the catalytic 


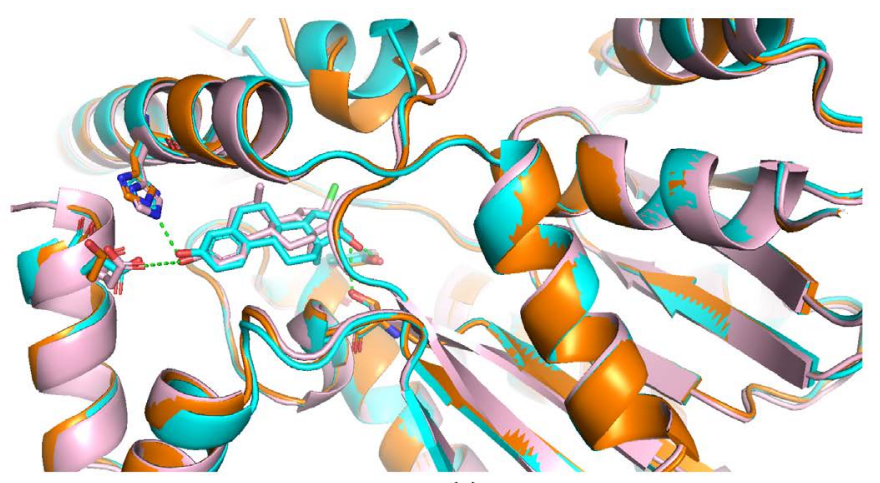

(a)

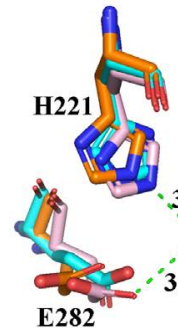

E282

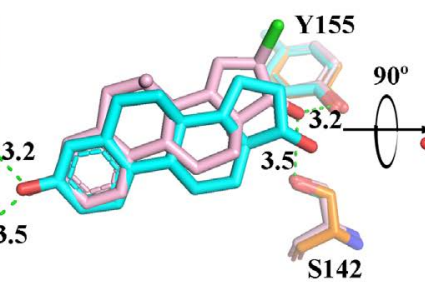

(b)

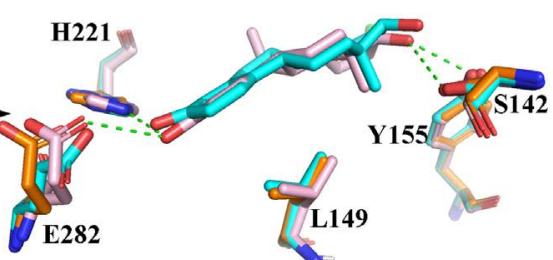

(c)

Figure 4. Superposition of A subunit of EM-139 (EM9) binary complex (pink) and E2 binary complex (cyan) along with $17 \beta$-HSD1 apo structure (orange), showing the steroid ligand binding sites. (a) General view of the active sites within the A subunit of EM-139 and E2 complex structures as well as the apo structure; (b) Top and (c) side view of the steroid binding sites in the superposed structures. Residues $\mathrm{Ser}^{142}, \mathrm{Leu}^{149}, \mathrm{Tyr}^{155}, \mathrm{His}^{221}$, and $\mathrm{Glu}^{282}$ are labeled and shown in sticks. Hydrogen bonds between EM-139 and surrounding residues are drawn in green dash lines and labeled. Chloride atom is colored in green.

end $\left(\mathrm{Ser}^{142}\right.$ and $\left.\mathrm{Tyr}^{155}\right)$ of the binding site are critical in stabilizing the bound inhibitor molecule. However, the introduction of a bulky side chain at the C-7 of the steroid core, which contributes to the anti-estrogenic activity of the dual-site inhibitor, may negatively affect the binding of inhibitor to $17 \beta$-HSD 1 . These results will contribute to the design of more potent and selective inhibitors of $17 \beta$-HSD1 for clinical purposes.

\section{Acknowledgements}

We thank Dre. M. Zhou for her technical support in enzyme purification and crystal growth. We acknowledge the use of beamline 31-LRL-CAT at the Advanced Photon Source, Argonne National Laboratory, USA.

\section{Conflicts of Interest}

The authors declare no conflicts of interest regarding the publication of this paper.

\section{References}

[1] Luu-The, V., Labrie, C., Zhao, H.F., Couët, J., Lachance, Y., Simard, J., Leblanc, G., Côté, J., Bérubé, D. and Gagné, R. (1989) Characterization of cDNAs for Human 
Estradiol 17beta-Dehydrogenase and Assignment of the Gene to Chromosome 17: Evidence of Two mRNA Species with Distinct 5'-Termini in Human Placenta. Molecular Endocrinology, 3, 1301-1309. https://doi.org/10.1210/mend-3-8-1301

[2] Miyoshi, Y., Ando, A., Shiba, E., Taguchi, T., Tamaki, Y. and Noguchi, S. (2001) Involvement of Up-Regulation of 17beta-Hydroxysteroid Dehydrogenase Type 1 in Maintenance of Intratumoral High Estradiol Levels in Postmenopausal Breast Cancers. International Journal of Cancer, 94, 685-689. https://doi.org/10.1002/ijc.1525

[3] Lin, S.X., Chen, J., Mazumdar, M., Poirier, D., Wang, C., Azzi, A. and Zhou, M. (2010) Molecular Therapy of Breast Cancer: Progress and Future Directions. Nature Reviews Endocrinology, 6, 485-493. https://doi.org/10.1038/nrendo.2010.92

[4] Cornel, K.M., Kruitwagen, R.F., Delvoux, B., Visconti, L., Van de Vijver, K.K., Day, J.M., Van Gorp, T., Hermans, R.J., Dunselman, G.A. and Romano, A. (2012) Overexpression of 17beta-Hydroxysteroid Dehydrogenase Type 1 Increases the Exposure of Endometrial Cancer to 17beta-Estradiol. The Journal of Clinical Endocrinology \& Metabolism, 97, E591-E601. https://doi.org/10.1210/jc.2011-2994

[5] Konings, G.F., Cornel, K.M., Xanthoulea, S., Delvoux, B., Skowron, M.A., Kooreman, L., Koskimies, P., Krakstad, C., Salvesen, H.B., van Kuijk, K., Schrooders, Y.J., Vooijs, M., Groot, A.J., Bongers, M.Y., Kruitwagen, R.F., ENITEC and Romano, A. (2018) Blocking 17beta-Hydroxysteroid Dehydrogenase Type 1 in Endometrial Cancer: A Potential Novel Endocrine Therapeutic Approach. The Journal of Pathology, 244, 203-214. https://doi.org/10.1002/path.5004

[6] Delvoux, B., D’Hooghe, T., Kyama, C., Koskimies, P., Hermans, R.J., Dunselman, G.A. and Romano, A. (2014) Inhibition of Type 1 17beta-Hydroxysteroid Dehydrogenase Impairs the Synthesis of 17beta-Estradiol in Endometriosis Lesions. The Journal of Clinical Endocrinology \& Metabolism, 99, 276-284.

https://doi.org/10.1210/jc.2013-2851

[7] Mori, T., Ito, F., Matsushima, H., Takaoka, O., Koshiba, A., Tanaka, Y., Kusuki, I. and Kitawaki, J. (2015) Dienogest Reduces HSD17beta1 Expression and Activity in Endometriosis. Journal of Endocrinology, 225, 69-76. https://doi.org/10.1530/JOE-15-0052

[8] Šmuc, T., Pucelj, M.R., Šinkovec, J., Husen, B., Thole, H. and Rižner, T.L. (2009) Expression Analysis of the Genes Involved in Estradiol and Progesterone Action in Human Ovarian Endometriosis. Gynecological Endocrinology, 23, 105-111. https://doi.org/10.1080/09513590601152219

[9] Blomquist, C.H., Bonenfant, M., McGinley, D.M., Posalaky, Z., Lakatua, D.J., Tuli-Puri, S., Bealka, D.G. and Tremblay, Y. (2002) Androgenic and Estrogenic $17 \beta$-Hydroxysteroid Dehydrogenase/17-Ketosteroid Reductase in Human Ovarian Epithelial Tumors: Evidence for the Type 1, 2 and 5 Isoforms. The Journal of Steroid Biochemistry and Molecular Biology, 81, 343-351. https://doi.org/10.1016/S0960-0760(02)00117-6

[10] Gunnarsson, C., Olsson, B.M. and Stål, O.; S. S. B. C. Group (2001) Abnormal Expression of 17beta-Hydroxysteroid Dehydrogenases in Breast Cancer Predicts Late Recurrence. Cancer Research, 61, 8448-8451.

[11] Vihko, P., Harkonen, P., Soronen, P., Torn, S., Herrala, A., Kurkela, R., Pulkka, A. Oduwole, O. and Isomaa, V. (2004) 17beta-Hydroxysteroid Dehydrogenases-Their Role in Pathophysiology. Molecular and Cellular Endocrinology, 215, 83-88. https://doi.org/10.1016/j.mce.2003.11.021

[12] Salhab, M., Reed, M.J., Al Sarakbi, W., Jiang, W.G. and Mokbel, K. (2006) The Role of Aromatase and 17-Beta-Hydroxysteroid Dehydrogenase Type 1 mRNA Expres- 
sion in Predicting the Clinical Outcome of Human Breast Cancer. Breast Cancer Research and Treatment, 99, 155-162. https://doi.org/10.1007/s10549-006-9198-8

[13] Poirier, D. (2010) 17 $\beta$-Hydroxysteroid Dehydrogenase Inhibitors: A Patent Review. Expert Opinion on Therapeutic Patents, 20, 1123-1145. https://doi.org/10.1517/13543776.2010.505604

[14] Lin, S.X., Poirier, D. and Adamski, J. (2013) A Challenge for Medicinal Chemistry by the $17 \beta$-hydroxysteroid Dehydrogenase Superfamily: An Integrated Biological Function and Inhibition Study. Current Topics in Medicinal Chemistry, 13, 1164-1171. https://doi.org/10.2174/15680266113139990004

[15] Trottier, A., Maltais, R., Ayan, D., Barbeau, X., Roy, J., Perreault, M., Poulin, R., Lague, P. and Poirier, D. (2017) Insight into the Mode of Action and Selectivity of PBRM, a Covalent Steroidal Inhibitor of 17beta-Hydroxysteroid Dehydrogenase Type 1. Biochemical Pharmacology, 144, 149-161. https://doi.org/10.1016/j.bcp.2017.08.004

[16] Day, J.M., Tutill, H.J., Purohit, A. and Reed, M.J. (2008) Design and Validation of Specific Inhibitors of 17beta-Hydroxysteroid Dehydrogenases for Therapeutic Application in Breast and Prostate Cancer, and in Endometriosis. Endocrine-Related Cancer, 15, 665-692. https://doi.org/10.1677/ERC-08-0042

[17] Poirier, D. (2011) Contribution to the Development of Inhibitors of 17beta-Hydroxysteroid Dehydrogenase Types 1 and 7: Key Tools for Studying and Treating Estrogen-Dependent Diseases. The Journal of Steroid Biochemistry and Molecular Biology, 125, 83-94. https://doi.org/10.1016/j.jsbmb.2010.12.007

[18] Brozic, P., Lanisnik Risner, T. and Gobec, S. (2008) Inhibitors of 17beta-Hydroxysteroid Dehydrogenase Type 1. Current Medicinal Chemistry, 15, 137-150. https://doi.org/10.2174/092986708783330629

[19] Levesque, C., Merand, Y., Dufour, J. M., Labrie, C. and Labrie, F. (1991) Synthesis and Biological Activity of New Halo-Steroidal Antiestrogens. Journal of Medicinal Chemistry, 34, 1624-1630. https://doi.org/10.1021/jm00109a014

[20] Lin, S.X., Han, Q., Azzi, A., Zhu, D.W., Gangloff, A. and Campbell, R.L. (1999) 3D-Structure of Human Estrogenic 17 $\beta$-HSD1: Binding with Various Steroids. The Journal of Steroid Biochemistry and Molecular Biology, 69, 425-429. https://doi.org/10.1016/S0960-0760(99)00062-X

[21] Labrie, C., Martel, C., Dufour, J.M., Lévesque, C., Mérand, Y. and Labrie, F. (1992) Novel Compounds Inhibit Estrogen Formation and Action. Cancer Research, 52, 610-615.

[22] Poirier, D. (2003) Inhibitors of $17 \beta$-Hydroxysteroid Dehydrogenases. Current Medicinal Chemistry, 10, 453-477. https://doi.org/10.2174/0929867033368222

[23] Zhu, D.W., Campbell, R., Labrie, F. and Lin, S.X. (1999) Crystallization and Preliminary Crystal Structure of the Complex of $17 \beta$-Hydroxysteroid Dehydrogenase with a Dual-Site Inhibitor. The Journal of Steroid Biochemistry and Molecular Biology, 70, 229-235. https://doi.org/10.1016/S0960-0760(99)00111-9

[24] Breton, R., Yang, F., Jin, J.Z., Li, B., Labrie, F. and Lin, S.X. (1994) Human $17 \beta$-Hydroxysteroid Dehydrogenase: Overproduction Using a Baculovirus Expression System and Characterization. The Journal of Steroid Biochemistry and Molecular Biology, 50, 275-282. https://doi.org/10.1016/0960-0760(94)90132-5

[25] Lin, S.X., Yang, F., Jin, J.Z., Breton, R., Zhu, D.W., Luu-The, V. and Labrie, F. (1992) Subunit Identity of the Dimeric 17 Beta-Hydroxysteroid Dehydrogenase from Human Placenta. Journal of Biological Chemistry, 267, 16182-16187. 
[26] Zhu, D.W., Azzi, A., Rehse, P. and Lin, S.X. (1996) The Crystallogenesis of a Human Estradiol Dehydrogenase-Substrate Complex. Journal of Crystal Growth, 168, 275-279. https://doi.org/10.1016/0022-0248(96)00331-4

[27] Leslie, A.G.W. and Powell, H.R. (2007) Processing Diffraction Data with Mosflm. Springer, Berlin. https://doi.org/10.1007/978-1-4020-6316-9_4

[28] Evans, P. (2006) Scaling and Assessment of Data Quality. Acta Crystallographica Section D Biological Crystallography, 62, 72-82. https://doi.org/10.1107/S0907444905036693

[29] Winn, M.D., Ballard, C.C., Cowtan, K.D., Dodson, E.J., Emsley, P., Evans, P.R., Keegan, R.M., Krissinel, E.B., Leslie, A.G., McCoy, A., McNicholas, S.J., Murshudov, G.N., Pannu, N.S., Potterton, E.A., Powell, H.R., Read, R.J., Vagin, A. and Wilson, K.S. (2011) Overview of the CCP4 Suite and Current Developments. Acta Crystallographica Section D Biological Crystallography, 67, 235-242. https://doi.org/10.1107/S0907444910045749

[30] Vagin, A. and Teplyakov, A. (2010) Molecular Replacement with MOLREP. Acta Crystallographica Section D Biological Crystallography, 66, 22-25. https://doi.org/10.1107/S0907444909042589

[31] Gangloff, A., Shi, R., Nahoum, V. and Lin, S.X. (2003) Pseudo-Symmetry of C19 Steroids, Alternative Binding Orientations, and Multispecificity in Human Estrogenic 17beta-Hydroxysteroid Dehydrogenase. FASEBJ, 17, 274-276. https://doi.org/10.1096/fj.02-0397fje

[32] Murshudov, G.N., Vagin, A.A., Lebedev, A., Wilson, K.S. and Dodson, E.J. (1999) Efficient Anisotropic Refinement of Macromolecular Structures Using FFT. Acta Crystallographica Section D Biological Crystallography, 55, 247-255. https://doi.org/10.1107/S090744499801405X

[33] Emsley, P., Lohkamp, B., Scott, W.G. and Cowtan, K. (2010) Features and Development of Coot. Acta Crystallographica Section D Biological Crystallography, 66, 486-501. https://doi.org/10.1107/S0907444910007493

[34] Laskowski, R.A., MacArthur, M.W., Moss, D.S. and Thornton, J.M. (1993) PROCHECK: A Program to Check the Stereochemical Quality of Protein Structures. Journal of Applied Crystallography, 26, 283-291. https://doi.org/10.1107/S0021889892009944

[35] Kleywegt, G.J. and Jones, T.A. (1996) Phi/Psi-Chology: Ramachandran Revisited. Structure, 4, 1395-1400. https://doi.org/10.1016/S0969-2126(96)00147-5

[36] Aka, J.A., Mazumdar, M., Chen, C.Q., Poirier, D. and Lin, S.X. (2010) 17beta-Hydroxysteroid Dehydrogenase Type 1 Stimulates Breast Cancer by Dihydrotestosterone Inactivation in Addition to Estradiol Production. Molecular Endocrinology, 24, 832-845. https://doi.org/10.1210/me.2009-0468

[37] Azzi, A., Rehse, P.H., Zhu, D.W., Campbell, R.L., Labrie, F. and Lin, S.X. (1996) Crystal Structure of Human Estrogenic $17 \beta$-Hydroxysteroid Dehydrogenase Complexed with 17 $\beta$-Estradiol. Nature Structural Biology, 3, 665-668. https://doi.org/10.1038/nsb0896-665

[38] Breton, R., Housset, D., Mazza, C. and Fontecilla-Camps, J.C. (1996) The Structure of a Complex of Human 17b-Hydroxysteroid Dehydrogenase with Estradiol and NADP+ Identifies Two Principal Targets for the Design of Inhibitors. Structure, 4, 905-915. https://doi.org/10.1016/S0969-2126(96)00098-6

[39] Shi, R. and Lin, S.X. (2004) Cofactor Hydrogen Bonding onto the Protein Main Chain Is Conserved in the Short Chain Dehydrogenase/Reductase Family and Contributes to Nicotinamide Orientation. The Journal of Biological Chemistry, 279, 
16778-16785. https://doi.org/10.1074/jbc.M313156200

[40] Sawicki, M.W., Erman, M., Puranen, T., Vihko, P. and Ghosh, D. (1999) Structure of the Ternary Complex of Human 17beta-Hydroxysteroid Dehydrogenase Type 1 with 3-Hydroxyestra-1,3,5,7-tetraen-17-one (equilin) and NADP+. Proceedings of the National Academy of Sciences, 96, 840-845.

https://doi.org/10.1073/pnas.96.3.840

[41] Zhu, D.W., Han, Q., Qiu, W., Campbell, R., Xie, B.X., Azzi, A. and Lin, S.X. (1999) Human 17 $\beta$-Hydroxysteroid Dehydrogenase-Ligand Complexes: Crystals of Different Space Groups with Various Cations and Combined Seeding and Co-Crystallization. Journal of Crystal Growth, 196, 356-364. https://doi.org/10.1016/S0022-0248(98)00848-3

[42] Ghosh, D., Pletnev, V.Z., Zhu, D.W., Wawrzak, Z., Duax, W.L., Pangborn, W., Labrie, F. and Lin, S.X. (1995) Structure of Human Estrogenic 17 Beta-Hydroxysteroid Dehydrogenase at 2.20 A Resolution. Structure, 3, 503-513. https://doi.org/10.1016/S0969-2126(01)00183-6

[43] Wakeling, A.E. and Bowler, J. (1989) Biology and Mode of Action of Pure Antioestrogens. Journal of Chemotherapy, 1, 1140-1141. 